\title{
MEDULLOBLASTOMA
}

\section{Evaluation of proliferative index by monoclonal antibody Mib-1, its prognostic correlation and therapeutic implications}

\author{
Antonio Fernandes Ferrari', Maria Betânia Mahler Araújo², \\ Paulo Henrique Aguiar ${ }^{3}$, José Pindaro Pereira Plese ${ }^{4}$
}

\begin{abstract}
In the past few years, the monoclonal antibody MIB-1 has been used by researchers in order to retrospectively study paraffin imbibed tumor fragments. The medulloblastoma is the most common malignant central nervous system tumor in childhood. The objectives were: determination of the mean Mib-1 LI value from these patients, as well as the prognostic value of the method.This retrospective study represents an analysis of the cellular proliferation index of posterior fossa medulloblastomas collected from 22 patients at A.C. Camargo Hospital, from January 1990 to December 1999. The histopathological diagnosis was confirmed by $H \& E$ and proliferative index (LI) was achived with Mib-1 which detects proliferating cells during G1, G2, S and $\mathrm{M}$ phases.The results demostrated that the mean Mib- 1 was 30,1\%, and ranged from $5,2 \%$ to $62,0 \%$.In conclusion, this method has prognostic value, has to be used as routine for patients harboring medulloblastomas and the ones who have PI greater than the mean value found in this study, should be treated aggressively.
\end{abstract}

KEY WORDS: medulloblastoma, labelling index (LI), MIB-1, prognostic factors.

\begin{abstract}
Meduloblastoma: avaliação do padrão proliferativo pelo anticorpo monoclonal Mib-1, correlação prognóstica e implicações terapêuticas

RESUMO - Nos últimos anos, o anticorpo monoclonal Mib1 tem sido bastante utilizado pelos pesquisadores para estudo retro e prospectivo, pela possibilidade de se obter um índice de proliferação de fragmentos tumorais conservados em parafina. O meduloblastoma é o tumor maligno mais freqüente do sistema nervoso central na infância. Os objetivos do trabalho foram determinar a média IP através do Mib-1 destas neoplasias, e estabelecer seu valor prognóstico. Neste trabalho foi determinado retrospectivamente o índice de proliferação celular de tumores extraídos de 22 pacientes portadores de meduloblastoma da fossa craniana posterior, tratados no Departamento de Neurocirurgia do Hospital A.C. Camargo de S. Paulo, no período de janeiro de 90 a dezembro de 99. 0 diagnóstico histopatológico de meduloblastoma foi confirmado pela coloração pela hematoxilina e eosina (HE) e o IP foi determinado através do marcador tumoral anticorpo monoclonal Mib1, que detecta as células em proliferação tumoral nas fases G1, G2, S e M do ciclo celular. Os resultados mostraram que a média do IP Mib1 foi de 30,1\%, e variou de 5,2\% a 62,0\%. A conclusão é que este método tem valor prognóstico, deve ser realizado como rotina no diagnóstico anatomopatológico dos pacientes portadores de meduloblastoma e que aqueles com IP Mib1 maior que a média deverão ser submetidos a tratamentos adjuvantes mais agressivos.
\end{abstract}

PALAVRAS-CHAVE: meduloblastoma, índice proliferativo (IP), Mib1, fatores prognósticos.

The behaviour of a brain neoplasm is not predictable by routine pathological diagnosis. Many parameters are involved in order to analize the biological behaviour of a brain tumor, however the proliferative index evaluated by MIB-1 has been applied to different types of brain neoplasm with important prognostic correlation ${ }^{1-7}$. MIB -1 is a monoclonal antibody (ma) which binds to a nucleolar proteins in the proliferative cell receptors, in all steps of the celular cycle, except in Go phase ${ }^{8}$. There are not many papers correlating both the medullobastoma and the MIB-1 proliferation index (LI) ${ }^{9-15}$.

\footnotetext{
Neurological Division of São Paulo Medical School (FMUSP) and Neuropathological Institute of AC Camargo Hospital of São Paulo, São Paulo SP, Brazil: 'Pos graduated; ${ }^{2}$ Patologist A.C. Camargo Hospital; ${ }^{3}$ Assistent Professor Neurosurgery FMUSP; ${ }^{4}$ Associated Professor Neurosurgery Department FMUSP.
}

Received 20 May 2002, received in final form 13 December 2002. Accepted 20 February 2003. 
We sampled restropectively 22 surgical cases of posterior fossa medulloblastoma, whose both clinical data and pathological specimens were available and analized immunohistochemically by means of the MIB-1. The LI were studied taking in concern their clinical prognosis.

\section{METHOD}

Clinical, surgical records and adjuvant treatment This study included 22 cases with histologically proven medulloblastomas, that were surgically treatead from January 1990 to December 1999, for which paraffin blocks were available. There were 13 male and 9 female patients. Patient age ranged from 2 to 39 years with a mean of $12,1 \%$ years ( standart deviation $S D=11.66$ ). The diagnostic was made on average about 3 months after the first symptom. The pre - operative clinical condition of the patients was analyzed: 21 cases with high intracranial hypertension $(\mathrm{ICH})$ and 1 with convulsive syndrome. Cerebellar syndrome was found in 17 cases. Regarding the grade of resection: 12 were submitted to a total resection, 8 subtotal resection and 2 partial resection. Preoperative ventricle peritoneal shunting (VPS) was performed in 8 patients and 2 patients were submitted to a post operative VPS.

Pathological materials - All paraffin blocks used in this study were obtained from surgical specimens.
Routine histologic types were reclassified, according to the World Health Organization system (WHO). Figure 1 (Case 4), shows the characteristic aspect of a medulloblastoma on routine diagnosis hematoxylin and eosin (HE), with small round cells and compact nucleus and pseudo-rosettes.

Immunohistochemical method and MIB - 1 staining index - Histological and immunohistochemical studies were performed on paraffin sections. Formalin fixed three $\mathrm{mm}$ sections were stained by hematoxylin and eosin and also by immunohistochemistry with monoclonal anti Ki-67 antigen clone Mib1 (Immunotech, catalog number 0505, France) using streptavidin-biotin-peroxidase complex technique. After deparaffinized and rehydrated, antigen retrieval was performed using $10 \mathrm{mM} \mathrm{pH} \mathrm{6,0} \mathrm{citrate}$ buffer solution in pressure cooker. Endogenous peroxidase activity was quenched by $3 \% \mathrm{H}_{2} \mathrm{O}_{2}$. Sections were incubated overnight at $4^{\circ} \mathrm{C}$ with antibody Mib1 diluted $1: 100$ in $1 \%$ bovine serum albumin and phosphate buffered solution (PBS). Slides were then incubated for $30 \mathrm{~min}$ at $37^{\circ} \mathrm{C}$ with biotinylated goat anti-mouse/rabbit Ig, followed by incubation for another 30 min at $37^{\circ} \mathrm{C}$ with the complex, streptavidin and biotinylated peroxydase (StreptABComplex/ HRP Duet, Dako, k492, USA). The color reaction was developed with 3,3' diaminobenzidine tetrahydrochloride (Sigma, D-5637, USA), $6 \% \mathrm{H}_{2} \mathrm{O}_{2}$ and PBS.

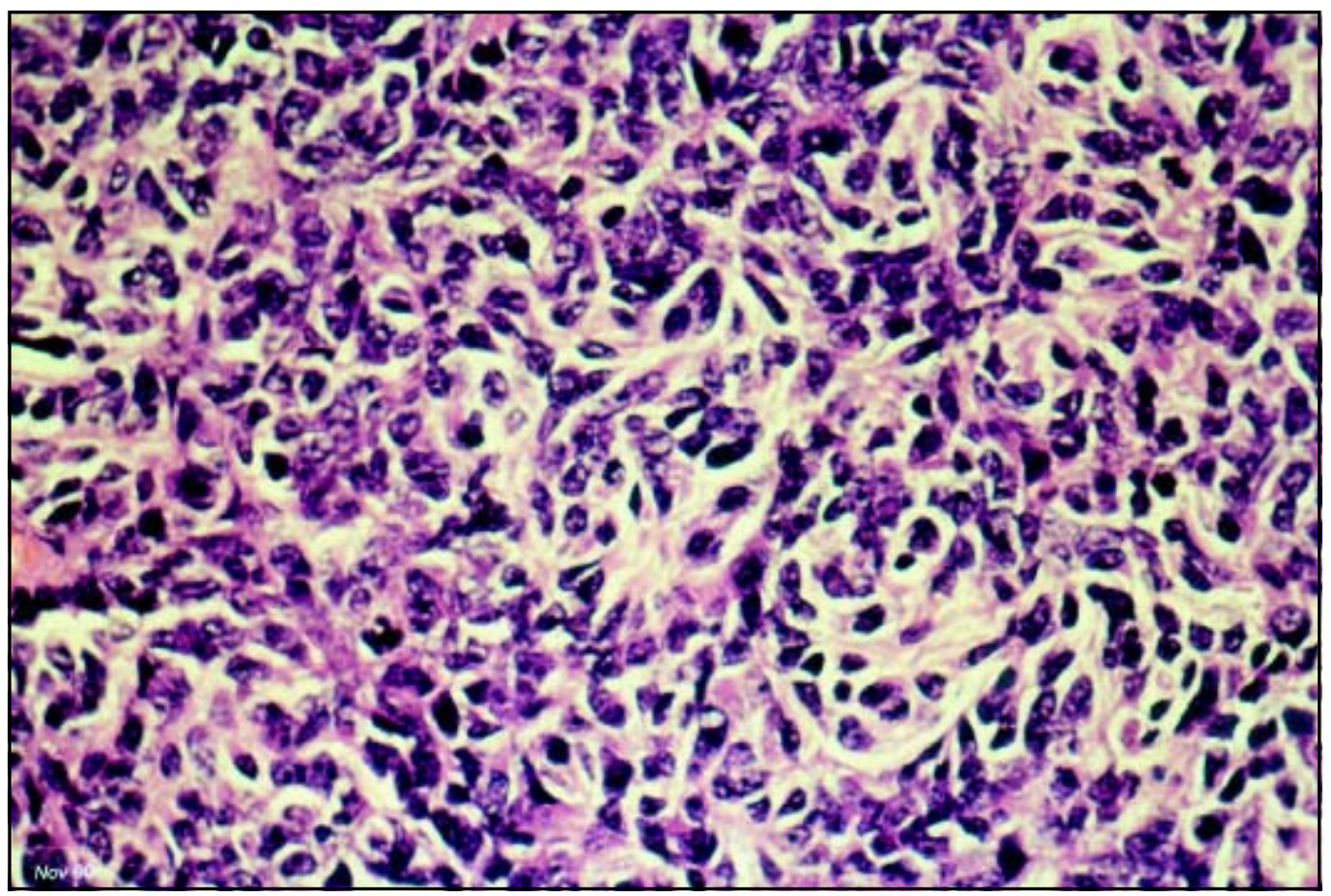

Fig 1. Case 2. Routine diagnostic with Hematoxilin and Eosin (H\&E) in case of Medulloblastoma. The pseudorosetes could be vizualized (400 X). 


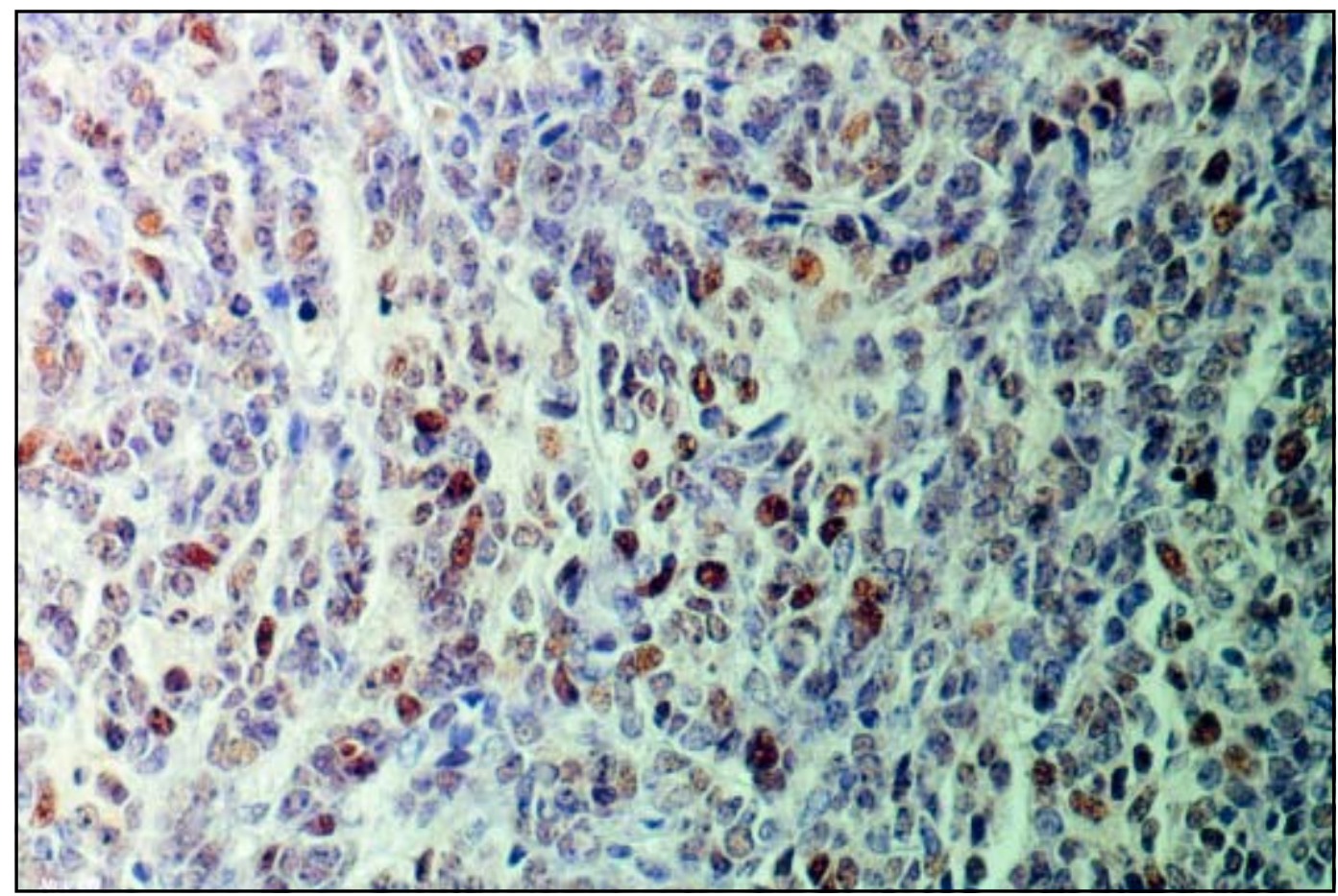

Fig 2. Case 15. Immunohistochemical analisys with MIB-1. Higher density of labeled cells. The Mib 1 was 35.50\% (DAB)(400X).

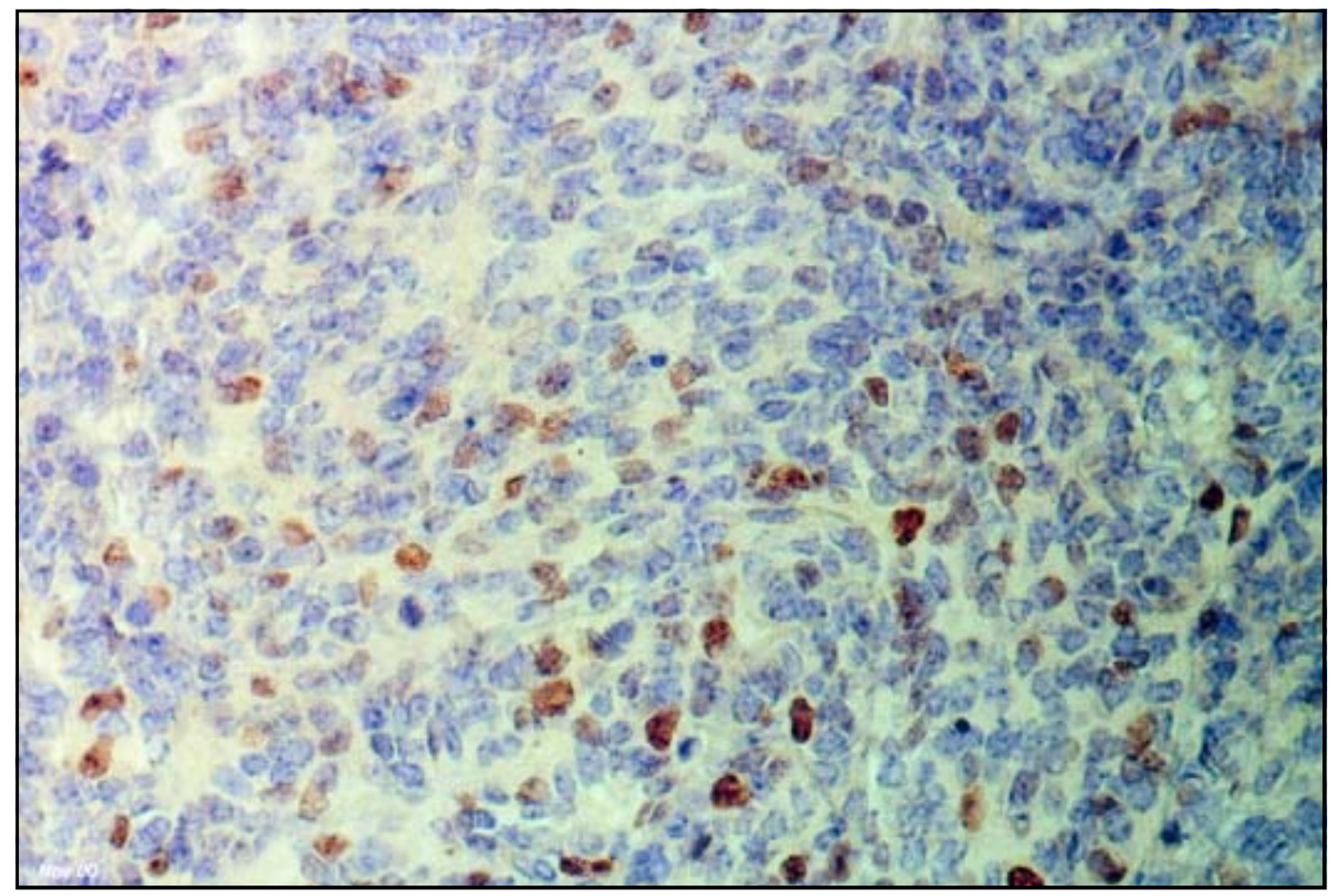

Fig 3. Case 6. Immunohistochemical analysis with MIB-1. Lower density of labeled cells. The Mib 1was 16.80\% (DAB) (400X).

Sections were counterstained with Harris hematoxylin, dehydrated and coverslipped. Positive and negative controls were included in this run.

The cell was classified positive when either the entire nucleous or a portion of the nucleous was stained. The number of positive and negative cells were scored in a total of 1,000 cells per section, by means of ocular grid under high power magnification (X 400), the entire section was examined. The labeling index (LI) or growth fraction was defined as the proportion of positive cells in relation to total of 1,000 cells evaluted (excluding labeled endothelial 
cells and lymphocytes). One reading was performed for each section in the 10 high power fields. The average LI (LI mean - individual case) was obtained by adding all labeled cells and dividing by 100 . Figures 2 and 3 show the labeled cells in the higher power field of a higher density of proliferative cells and lower density of proliferative cells.

Evaluation of preoperative computerized tomography (CT) - The authors reviewed the preoperative $\mathrm{CT}$ in order to determine the tumour location and hydrocephalus. The location of the tumors were: 16 cerebellar midline and 6 hemisphericals. There were 21 cases with obstructive ventriculomegaly.

Evaluation of adjuvant treatment - Radiotherapy and chemotherapy were used in 14 patients. Chemotherapy without radiotherapy was necessary in 5 patients. Radiotherapy without chemotherapy only 2 patients. One patient had no adjuvant treatment due to death in the first postoperative month.

Survival period and follow up - The survival time was 0.1 to 8.6 years (average $=3.8$ years). After 10 years, only 7 patients were alive.

Statistical method - Data was entered into a database on a personal computer and analyzed using a statistical program. The chosen gold standard is the MIB - 1 LI. To verify the correlation of the MIB - 1 with the clinical outcome (multiple comparison) statisticals analyses were used including the MannWhitney (2 averages), or Kruskal-Wallis (3 or more averages). The Survival period was analyzed by means of Kaplan Meier and the logrank test comparison between the mathematical curves of survival. Statistical significance was determined at a $p$ value below 0.05 .

\section{RESULTS}

Proliferative index (MIB-1LI) - The MIB-1 LI of all patients are found on Table 1. The mean MIB-1 LI was $30.1 \%$ (ranged from 5.2 to $62.0 \%, S D=13.9 \%$ ).

MIB-1 LI and survival - The patients with MIB-1LI with values from 5.2 to $30.1 \%$ showed probability of survival of $71 \%$ in one year, $64 \%$ in 3 years and $49 \%$ in 5 years. The patients with values higher than $30.1 \%$ showed probability of survival of $75 \%$ in 1 year, $16 \%$ in 3 years and $0 \%$ in 5 years since the beginning of treatment. $(p=0.0367)$. This data is summarized on Table 2.
Table 1. Labeling index of medulloblasmas analisys of 22 cases.

\begin{tabular}{cccc}
\hline Patient & MIB-1 LI (\%) & Patient & MIB-1 LI (\%) \\
\hline 1 & $27.2(\%)$ & 12 & $44.8(\%)$ \\
2 & $25.0(\%)$ & 13 & $25.4(\%)$ \\
3 & $7.2(\%)$ & 14 & $39.0(\%)$ \\
4 & $28.0(\%)$ & 15 & $35.5(\%)$ \\
5 & $27.6(\%)$ & 16 & $16.9(\%)$ \\
6 & $16.8(\%)$ & 17 & $5.2(\%)$ \\
7 & $26.5(\%)$ & 18 & $44.8(\%)$ \\
8 & $22.1(\%)$ & 19 & $62.0(\%)$ \\
9 & $24.7(\%)$ & 20 & $41.0(\%)$ \\
10 & $20.7(\%)$ & 21 & $46.3(\%)$ \\
11 & $26.8(\%)$ & 22 & $44.80(\%)$ \\
\hline
\end{tabular}

Mean 30.1 (\%), SD 13.9 (\%).

Table 2. Comparison between MIB-1LI and period of survival in medulloblastomas.

\begin{tabular}{lcccc}
\hline Period of Survival & 1 year & 3 year & 5 year & \\
\hline MIB-1 LI < 30.1\% & $71 \%$ & $64 \%$ & $49 \%$ & Probability (\%) \\
MIB-1 LI > 30.1\% & $75 \%$ & $16 \%$ & $0 \%$ & Probability (\%) \\
\hline $\mathrm{p}=0.0367$ & & & &
\end{tabular}

\section{DISCUSSION}

Medulloblastoma is the most common solid tumor in childhood, showing an incidence of $25 \%$ in the group of brain tumors at this age. In the past ten years this incidence has been decreasing as described by many authors. The cause of this remains still unknown ${ }^{16}$. According to the literature review, the probability of survival after 5 year-treatment is lower in the high risk group than in the low risk group of patients ${ }^{17}$. The higher risk group of patients is under 3 years-old, partial resection tumor, spreading tumor with metastasis in the central nervous system ${ }^{18}$. Rutka and co-workers ${ }^{16}$ found $80 \%$ of 5 year -survival rate in the low risk patients and $40 \%$ in the high risk patients. In our series we have found $48 \%$ of 5 -year-survival rate and $0 \%$ of 5 year-survival rate respectively.

The mean MIB-1 LI found in literature was 20.9 (ranged from 13.1 to $30.9 \%)^{10-14}$. The present study showed a mean MIB-1LI of $30.10 \%$ (ranged 5.2 to $60.0 \%$ ). Our mean MIB-1 LI was higher than the 
literature reviewed due probably to differences of the immunohistochemical methods, and because we used 10 fields with higher grade of labeled cells which could increase the number of labeled cells on avarege.

It seems that a patient harboring a medulloblastoma with higher MIB1 LI should have a worse prognosis than a patient with lower, however it has never been proved before on literature with a significant number of patients. Ito and co-workers ${ }^{15}$ described a similar relationship between $\mathrm{Li}$ and prognosis, although no significant statistical support was found by others ${ }^{13,14,19}$.

The definition of risk criteria for survival in medulloblastoma is still controversial $17,18,20$. The fourth floor ventricle invasion by the tumour was taken in concern by Bailey and co-workers ${ }^{17}$, associated to other risks listed above, neverthless we could suggest formally the inclusion of MIB-1LI as a strong factor of predictable risk.

In light of above the MIB-1 LI is a prognostic factor regarding patients with medulloblastoma. This method should be employed routinelly in the group of patients harboring medulloblastomas, and the ones who have MIB-1 LI greater than $30.1 \%$ ought to be treated aggressively.

\section{REFERENCES}

1. Aguiar PH, Tatagiba M, Samii M, Ostertag H. Métodos de estudo do potencial proliferativo das neoplasias primárias do sistema nervoso central. Valor prognóstico e implicação terapêutica. Arq Bras Neurocirurg 1993;12:207-222.
2. Ostertag CB, Volk B, Shibata T, Burger P, Kleihues P. The monoclonal antibody Ki-67 as a maker for proliferating cells in stereotatic biopsies of brain tumors. Acta Neurochir (Wien) 1987;89:117-121.

3. Aguiar PH, Meningiomas. Estudo do índice de proliferação celular por meio do anti-corpo monoclonal Mib1. Correlação com características clínico-radiológicas e histológicas. Tese, Universidade de São Paulo. São Paulo, 1998.

4. Siffert J, Allen JC. Medulloblastoma. In Vinker PJ, Bruyn GH (eds). Handbook of clinical neurology, Vol. 24.Amsterdam, North - Holland, 1997:181-209.

5. Aguiar PH, Tatagiba M, Samii M et al. Proliferative Activity Of Acoustic Neurilenomas Without Nerofibromatosis Determined By Monoclonal Antibody Mib I. Acta Neurochir (Wien) 1995;134:35-39.

6. Tatagiba M, Samii M, Dankoweit-Timpe E, et al. Esthesioneuroblastomas With intracranial extension: proliferative potential and management. Arq Neuropsiquiatr 1995;53:577-586.

7. Tella OJ, Herculano MA, Delcelo R. Adenomas hipofisários:. relação entre invasividade e índice proliferativo tumoral. Arq Neuropsiquiatr 2000;58:1055-1063.

8. Cattoretti G, Becker MHG, Key G et al. Monoclonal antibodies against recombinant parts of Ki-67 antigen (MIB1 and MIB3) detect proliferating cells in microwave - processed formalin - fixed paraffin sections. J Pathol 1992;168:357-363.

9. Giordana MT, Cavalla P, Chio A, et al. Prognostic factor in adult medulloblastoma: a clinico pathologic study. Tumori 1995;81:338-346.

10. Iijima M, Nakazato Y. Pale islands in medulloblastoma consist of differentiated cells with low growth potential. Path Inter 1997;47:25-30.

11. Karamitopoulou E,Perentes E, Melachrinou M, Maraziots T. Proliferating cell nuclear antigen immunoreactivity in human central nervous system neoplasms. Acta Neuropathol 1993;85:316-322.

12. Tsanaclis AM, Robert F, Michaud J, Brem S. The cycling pool of cells within human brain tumors: in situ cytokinetics using the monoclonal antibody Ki-67. Can J Neurol Sci 1991;18:12-17.

13. Miralbell R, Markus T, Sabine B, et al. Pediatric medulloblastoma: prognostic value of p53, bcl-2, Mib-1 and microvessel density. J NeuroOncol 1999;45:103-110.

14. Schiffer D, Cavalla P, Migheli A, et al. Apoptosis and cell proliferation in human neuroepithelial tumors. Neurosci Lett 1995;195:81-84.

15. Ito S, Hoshino T, Prados MD, Eduards MSB. Cell kinetics of medulloblastomas. Cancer 1992;70:671-678.

16. Rutka JT. Medulloblastoma, Clin Neurosurg 1996;44:571-85.

17. Bailey CC, Gnekow A, Wellek S, et al. Retrospective randomised trial of chemotherapy given before radiotherapy. Med Pediatr Oncol 1995;25:166-178.

18. Choux M, Lena G, Gentet JC, Paredes AP. Medulloblastoma. Pediatr Neurosurg 2001;72:804-821.

19. Jay V, Parkinson D, Becker L et al. Cell Kinetic analysis in pediatric brain and spinal tumors: a study of 117 cases with Ki-67 quantitation and flow cytometry. Pediatri Pathol 1994;14:253-276.

20. Taylor MD, Rutka JT. Molecular biology of pediatric brain tumors. Pediatr Neurosug 2001;84:923-950. 